\title{
Pyrrolidine nucleotide analogs with a tunable conformation
}

\author{
Lenka Poštová Slavětínská, Dominik Rejman and Radek Pohl ${ }^{*}$
}

\author{
Full Research Paper \\ Address: \\ Institute of Organic Chemistry and Biochemistry, Academy of \\ Sciences of the Czech Republic, Flemingovo nám. 2, 16610 Prague \\ 6, Czech Republic \\ Email: \\ Radek Pohl ${ }^{*}$ - pohl@uochb.cas.cz \\ * Corresponding author \\ Keywords: \\ conformation; NMR; nucleic acids; nucleotide analog; phosphonic \\ acid; pseudorotation; pyrrolidine
}

Open Access

\author{
Beilstein J. Org. Chem. 2014, 10, 1967-1980. \\ doi:10.3762/bjoc. 10.205
}

Received: 28 May 2014

Accepted: 05 August 2014

Published: 22 August 2014

This article is part of the Thematic Series "Nucleic acid chemistry".

Guest Editor: H.-A. Wagenknecht

C 2014 Poštová Slavětínská et al; licensee Beilstein-Institut. License and terms: see end of document.

\begin{abstract}
Conformational preferences of the pyrrolidine ring in nucleotide analogs 7-14 were investigated by means of NMR and molecular modeling. The effect of the relative configuration of hydroxy and nucleobase substituents as well as the effect of the alkylation or acylation of the pyrrolidine nitrogen atom on the conformation of the pyrrolidine ring were studied. The results of a conformational analysis show that the alkylation/acylation can be effectively used for tuning the pyrrolidine conformation over the whole pseudorotation cycle.
\end{abstract}

\section{Introduction}

Nucleotides, nucleosides and nucleobases play an important role in all biological systems. Therefore, it is not surprising that many of their analogs possess interesting biological properties. Potent antiviral drugs based on phosphonate nucleotides 1a-c $[1,2], \mathbf{2 a}-\mathbf{d}$ and 3a-d (Figure 1) have been reported. Prodrugs of acyclic compounds 1a-c are currently in clinical use for the treatment of diseases caused by DNA viruses and retroviruses. Cyclic analogs $\mathbf{2}$ and $\mathbf{3}$ were reported to exhibit antiviral activity against HIV strains [3]. These examples show that the modification of the sugar-phosphate moiety in nucleotides is a successful approach in developing antiviral therapeutics.

Our long-term interest in the synthesis and evaluation of biological properties of phosphonate azanucleotides has yielded several potent inhibitors of nucleoside/nucleotide metabolizing enzymes: thymine derivatives $\mathbf{4}$ and $\mathbf{1 1}$ (Figure 1 and Figure 2) - inhibitors of thymidine phosphorylase isolated from spontaneous lymphoma of SD rats ( $\mathrm{IC}_{50}=15$ and $11 \mathrm{nM}$, respectively) [4], guanine derivative 5 - a potent inhibitor of human purine nucleoside phosphorylase PNP $\left(K_{\mathrm{i}}=10 \mathrm{nM}\right)$ [5], and finally guanine derivative $\mathbf{6}$ - exhibiting inhibitory activity against 6-oxopurine phosphoribosyltransferases from Escherichia coli [6]. These biologically active analogs contain a five-membered pyrrolidine ring, whose conformation has not been explored so far.

It is known that the conformation of a five-membered ribose or deoxyribose ring plays an important role in the nucleoside, 


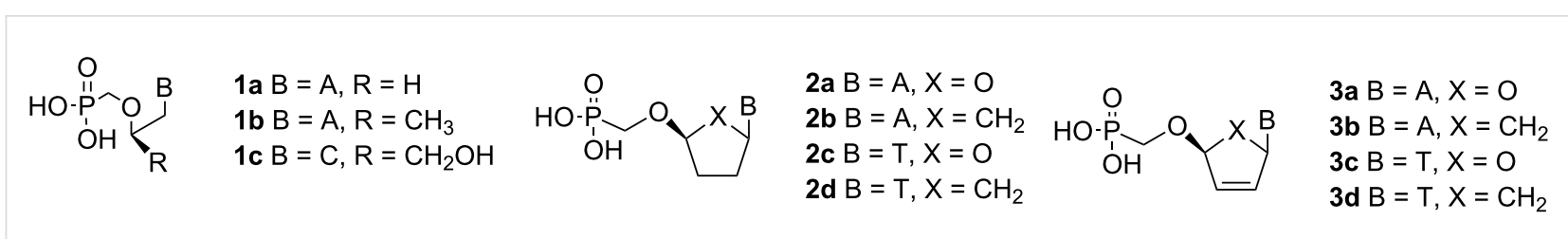

$A=$ adenin-9-yl; $C=$ cytosin-1-yl; $T$ = thymin-1-yl
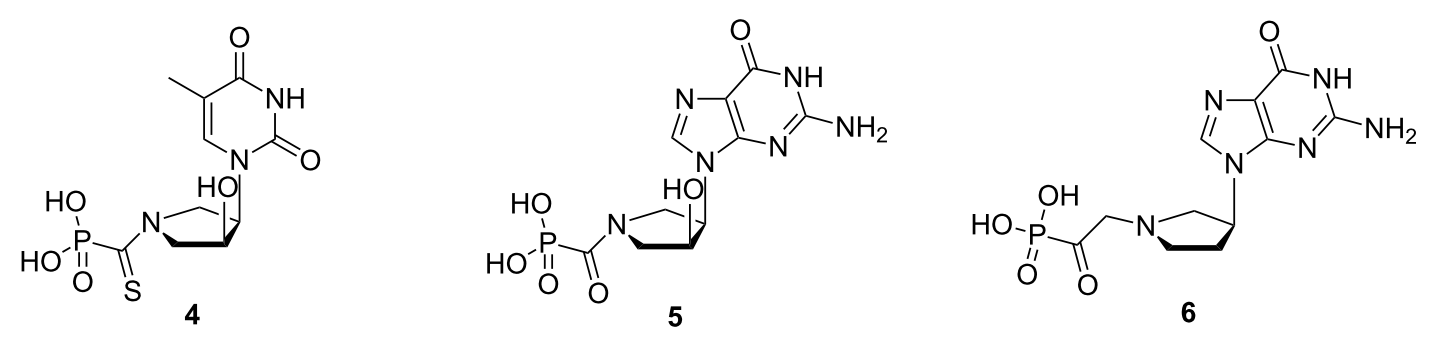

Figure 1: Examples of biologically active acyclic and cyclic nucleotide analogs.

nucleotide and oligonucleotide spatial structure. The conformation predefines, for example, the stability of DNA:RNA duplexes - complexes between oligodeoxyribonucleotide and a complementary RNA strain [7] or an overall shape of oligonucleotide. It is also well known that the structure of DNA may alternate between $\mathrm{A}, \mathrm{B}$ and $\mathrm{Z}$ forms depending on the hydration and the type and concentration of metal ions, which is also reflected in the conformation of the sugar part. Finally, the conformation of ribose or its mimics also significantly predetermines the binding of a nucleoside, nucleotide or an analog thereof to an active site of a particular enzyme. The knowledge of the conformation of nucleosides, nucleotides and their analogs is therefore essential for the understanding or even prediction of their biological properties.

There are several approaches providing information on the conformation of a five-membered ring. Conformational analysis using vicinal proton-proton scalar couplings $\left({ }^{3} J_{\mathrm{HH}}\right)$ of ring protons obtained from ${ }^{1} \mathrm{H}$ NMR spectra is a traditional and well-established experimental method. ${ }^{3} J_{\mathrm{HH}}$ encodes information on the exocyclic dihedral angle between coupled protons based on the Karplus relationship [8]. Exocyclic dihedral angles are in turn in direct relation with endocyclic dihedral angles between ring atoms defining the conformation of the fivemembered ring based on the pseudorotation concept [9]. This straightforward approach is complicated by the presence of more than one rapidly interconverting conformer in solution, resulting in the observation of averaged experimental ${ }^{3} J_{\mathrm{HH}}$. Nevertheless, even these averaged ${ }^{3} J_{\mathrm{HH}}$ can be used for conformational analysis by means of the program PSEUROT [10], which minimizes differences between experimental and calculated ${ }^{3} J_{\mathrm{HH}}$, assuming a two-state equilibrium of conformers. The output of the PSEUROT provides pseudorotation parame- ters: phase angles $(P)$, the maximum puckering amplitudes $\left(\Phi_{\max }\right)$ and the relative amounts of individual conformers. The original PSEUROT program was later complemented with the program MULDER [11]. Recently, the Matlab Pseudorotation GUI version of the program has been developed, enabling the creation of conformational maps [12].

The conformational analysis using PSEUROT-based programs was originally designed for ribose or deoxyribose, but in general it can be used for any saturated five-membered ring. The program PSEUROT was, for example, used in a conformational analysis of the prolyl ring in aminoethylprolyl peptide nucleic acid monomers [13], or in a conformational analysis of 2'-fluoro-4'-thioarabinothymidine [14]. The performance of the Matlab Pseudorotation GUI program was tested on two 4'-thio-2'deoxynucleoside analogs [12].

In this publication, we present a conformational analysis of pyrrolidine azanucleotide analogs 7-14 containing thymine and adenine as examples of pyrimidine and purine nucleobases, respectively (Figure 2), and show how the conformation is affected by the mode of the phosphonate moiety attachment to the pyrrolidine ring. Particularly, we show that the alkylation or acylation (an amine or an amide bond formation) of the pyrrolidine nitrogen atom can be used for a simple but effective tuning of pyrrolidine-ring conformation in compounds 7-14.

\section{Results and Discussion Chemistry}

Phosphonomethyl derivatives 7-10 were prepared from pyrrolidine azanucleosides 15a-d [5,15] via a Mannich-type reaction with diisopropyl phosphite and aqueous formaldehyde at elevated temperature in good yields (Scheme 1). The obtained 
<smiles>Cc1c[nH]c(=O)[nH]c1=O</smiles><smiles>O=P(O)(O)CN1CC2CNC(C2)C1</smiles>

7<smiles></smiles><smiles>CN1CC2CC(C1)CN(C(=O)P(O)(O)(O)O)C2</smiles>

11<smiles>Cc1cn(C2CCCCC2)c(=O)[nH]c1=O</smiles><smiles>Nc1ncnc2c1ncn2C1CN(CP(=O)(O)O)CC1O</smiles><smiles>Nc1ncnc2c1ncn2C1CCCCC1CN(CP(=O)(O)O)C(=O)O</smiles>

10<smiles>Nc1ncnc2c1ncn2C1CN2CC(O)C1C2</smiles>

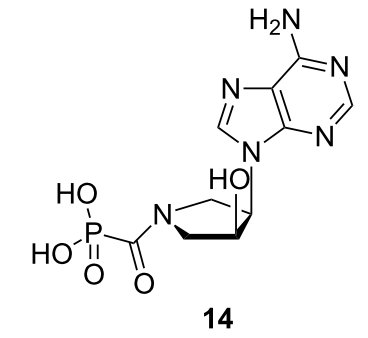

Figure 2: The pyrrolidine nucleotide analogs investigated in this study.<smiles>[R][R]1C2CN(CP(=O)(OC(C)C)OC(C)C)CN1CC2[R]</smiles>

$\mathrm{H}_{2} \mathrm{CO}, \mathrm{HP}(\mathrm{O})(\mathrm{OiPr})_{2}$

17a-d<smiles>Cc1cn(C2CN3CCCCC2C3)c(=O)[nH]c1=O</smiles>

14 
the pyrrolidine ring, the nucleobase and the endocyclic phase angles $\Phi_{0}-\Phi_{4}$ for the purposes of the conformational analysis is shown in Figure 3. There are fundamental differences in the NMR spectra of phosphonomethyl and phosphonoformyl derivatives, which will be commented on in detail in the following paragraphs.

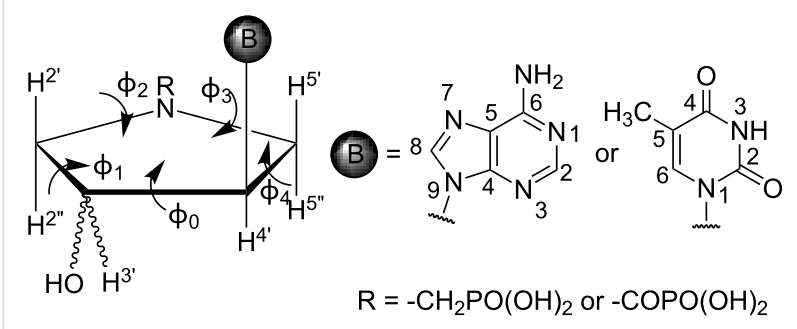

Figure 3: The numbering of the pyrrolidine ring, the nucleobase and the endocyclic phase angles for the purposes of the conformational analysis.

\section{NMR study of phosphonomethyl derivatives}

Phosphonomethyl derivatives 7-10 contain both basic (pyrrolidine) and acidic (phosphonic acid) functionalities. Therefore, several protonation/deprotonation transitions are expected to take place when scanning a $\mathrm{pH}$ scale. In order to determine these transitions, we measured NMR spectra of 7-10 at different $\mathrm{pD}$ values using $\mathrm{D}_{2} \mathrm{O}$ solutions of $\mathrm{DCl}$ or $\mathrm{NaOD}$ for decreasing or increasing $\mathrm{pD}$, respectively. We found that the NMR spectra of 7-10 are strongly pD-dependent as demonstrated for example on the ${ }^{1} \mathrm{H}$ NMR spectrum of adenine derivative 9 (Figure 4).

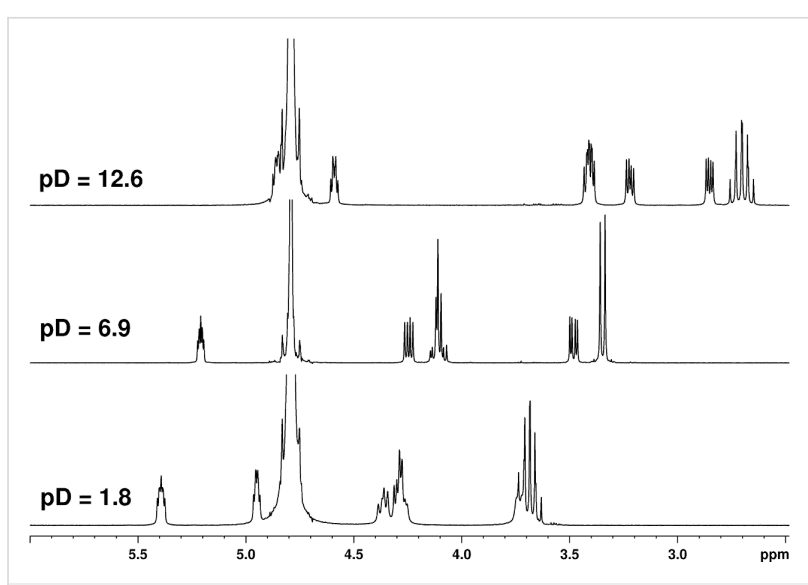

Figure 4: The aliphatic part (pyrrolidine protons) of the ${ }^{1} \mathrm{H}$ NMR spectra of 9 measured in $\mathrm{D}_{2} \mathrm{O}$ at different $\mathrm{pD}$ values.

As follows from $\mathrm{pD}$ titrations (Figure 5; for more details see Supporting Information File 1), phosphonomethyl analogs $\mathbf{7 - 1 0}$, both cis $(\mathbf{8}, \mathbf{1 0})$ and trans $(\mathbf{7}, \mathbf{9})$, exist at a very low $\mathrm{pD}$ value $(<3)$ as free phosphonic acids with a deuterated pyrrolidine nitrogen atom (Figure 6). The phosphonic acid moiety goes through a two-stage deuteration/dedeuteration transition at $\mathrm{pD} \sim 3$ and 5 and the pyrrolidine nitrogen atom stays deuterated until $\mathrm{pD} \sim 9$. This suggests that the compounds exist as zwitterions with a hydrogen bond between the negatively charged phosphonate moiety and the positively charged pyrrolidine nitrogen atom in the range of $\mathrm{pD} 3-9$. The $\mathrm{pD}$ titration experiments have also revealed the deuteration/dedeuteration of adenine and thymine nucleobases. In agreement with the data reported [16,17], adenine becomes deuterated predominantly on
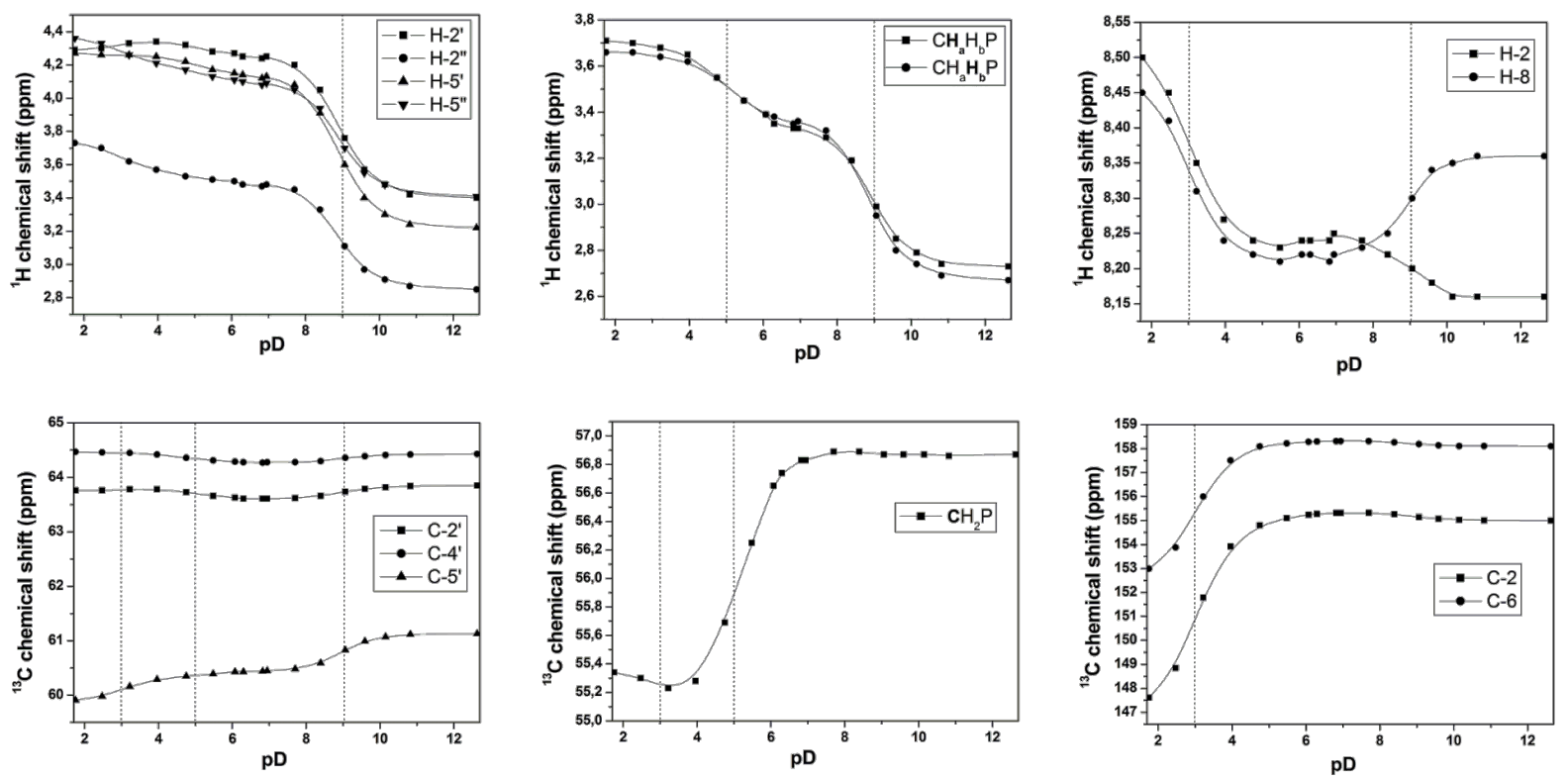

Figure 5: Changes of selected ${ }^{1} \mathrm{H}$ and ${ }^{13} \mathrm{C}$ chemical shifts of 9 upon $\mathrm{pD}$ change. 

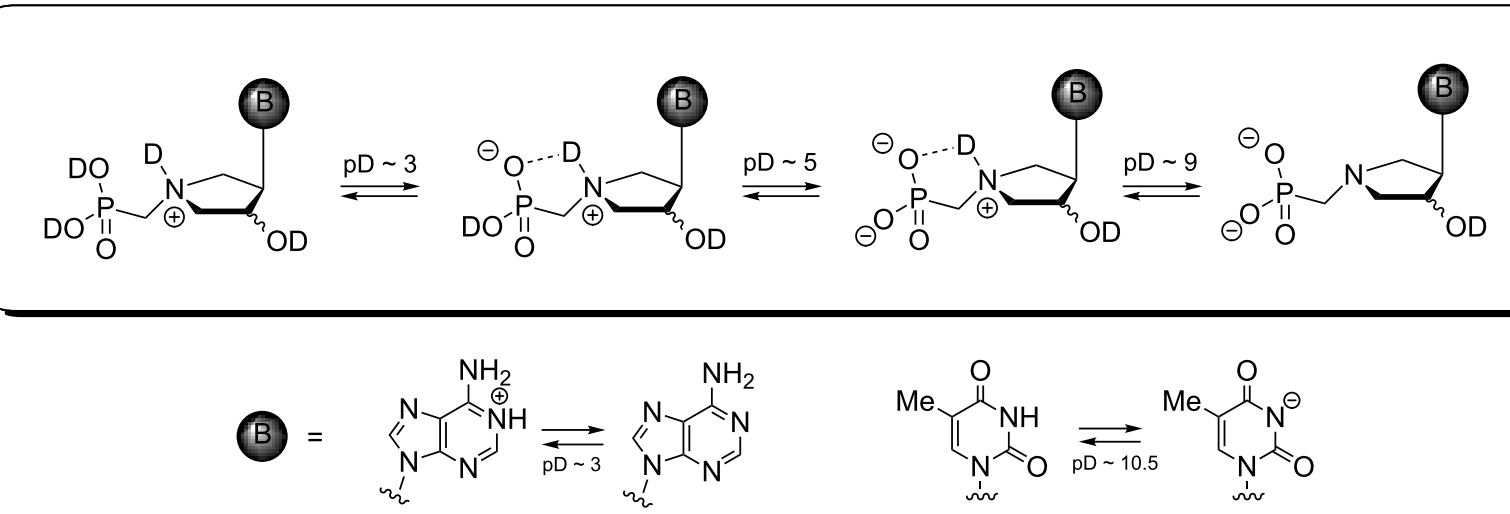

Figure 6: The deuteration equilibria of phosphonomethyl derivatives 7-10

$\mathrm{N}-1$ at $\mathrm{pD} \sim 3$ while thymine releases its deuterium at N-3 at $\mathrm{pD} \sim 10.5$ and becomes negatively charged. Typically, a $\mathrm{pD}$ value of 5.7-6.9 was reached when $50 \mathrm{mM}$ solutions of 7-10 in $\mathrm{D}_{2} \mathrm{O}$ were prepared for the NMR measurement, which indicates that isolated compounds are in the form of the monosodium monozwitterionic salt.

The orientation of the phosphonomethyl moiety relative to the nucleobase in the zwitterionic form could be theoretically deduced from the H,H-ROESY spectra. In real spectra, however, protons from $\mathrm{CH}_{2} \mathrm{PO}(\mathrm{OH})_{2}$ provide NOE contacts to protons on both sides of the pyrrolidine ring, suggesting an exchange of deuterium connected to the pyrrolidine nitrogen.

\section{NMR study of phosphonoformyl derivatives}

In contrast to $\mathbf{7 - 1 0}$, an amidic pyrrolidine nitrogen atom in phosphonoformyl derivatives 11-14 is not involved in protonation/deprotonation transitions. Only negligible changes of ${ }^{1} \mathrm{H}$ chemical shifts were observed when the $\mathrm{pD}$ value of the solution was changed as demonstrated in the example of compound 13 (Figure 7).

Indeed, the reason is the delocalization of the lone electron pair on the pyrrolidine nitrogen atom by resonance. This brings, in addition to the lack of basicity, the existence of two amide rotamers A and B (Figure 8), which can be observed in NMR spectra as two sets of signals. The ratio of $A: B$ is about 1:1 with a slight excess of rotamer B (see the Experimental and Supporting Information File 1).

The existence of the two rotamers prompted us to estimate the energy barrier of their interconversion. We therefore performed variable ${ }^{31} \mathrm{P}$ NMR measurements of $\mathbf{1 4}$ at different temperatures (starting at $25^{\circ} \mathrm{C}$ with a $10{ }^{\circ} \mathrm{C}$ step, with the last measurement taken at $100^{\circ} \mathrm{C}$ ) and a line-shape analysis of an uncou-

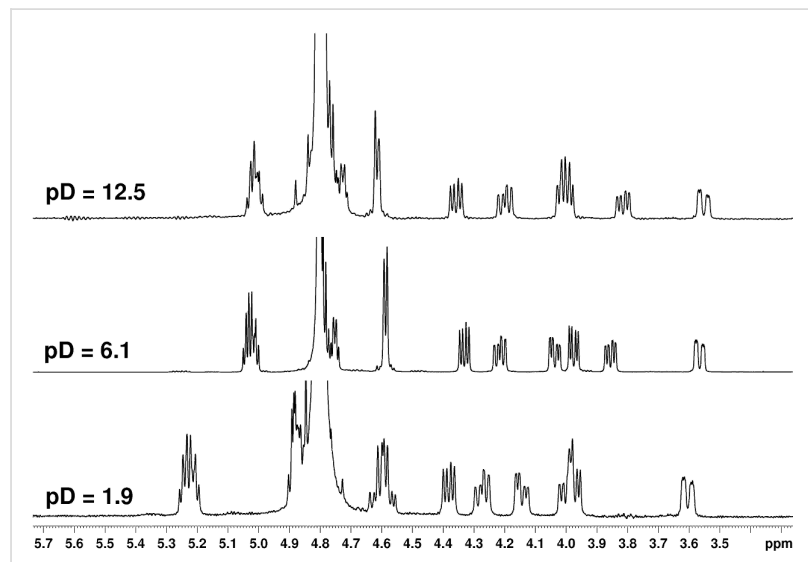

Figure 7: The aliphatic part (pyrrolidine protons) of the ${ }^{1} \mathrm{H}$ NMR spectra of 13 measured in $D_{2} \mathrm{O}$ at different $\mathrm{pD}$ values.

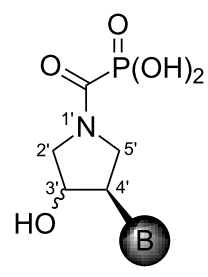

rotamer $\mathrm{A}$

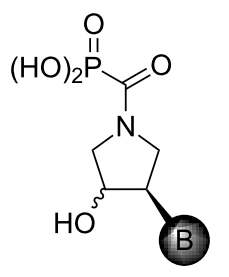

rotamer $\mathbf{B}$
B = thymine-1-yl or adenine-9-yl

Figure 8: Amide rotamers of phosphonoformyl derivatives 11-14.

pled, exchanging two-site ${ }^{31} \mathrm{P}$ system (Figure 9). This enabled us to obtain the rate constants of the exchange at different temperatures and estimate the activation parameters of the interconversion such as the Gibbs free energy of activation $\Delta G^{\ddagger} 298=$ $80.7 \mathrm{~kJ} / \mathrm{mol}$; the enthalpy of activation $\Delta H^{*}=23.8 \mathrm{~kJ} / \mathrm{mol}$; and the entropy of activation $\Delta S^{\dagger}=-190.6 \mathrm{~J} /(\mathrm{K} \cdot \mathrm{mol}$ ) (for details, 
see Supporting Information File 1). The relatively low value of $\Delta G^{\ddagger} 298=80.7 \mathrm{~kJ} / \mathrm{mol}$ implies that the preparative isolation of the individual rotamers $\mathrm{A}$ and $\mathrm{B}$ at room temperature would not be possible.

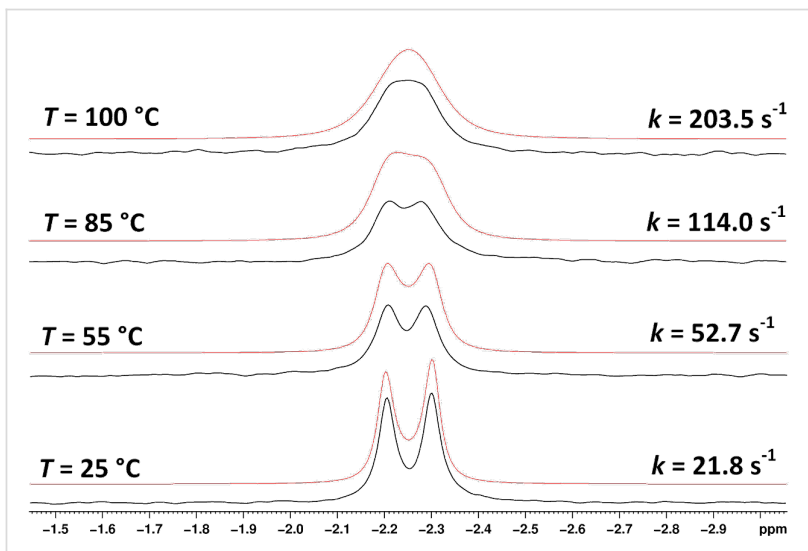

Figure 9: The ${ }^{31} \mathrm{P}$ NMR spectra (202.3 MHz) of 14 measured (the black curve) and simulated (the red curve) at various temperatures.

For the purposes of conformational analysis, it was necessary to assign correctly the NMR signals of the individual conformers. We noticed that only one of the C-2' or C-5' signals in the particular rotamer is split in the ${ }^{13} \mathrm{C}$ NMR spectrum due to ${ }^{3} J(\mathrm{C}, \mathrm{P})$ spin-spin interaction. In harmony with the general dependence of the vicinal coupling constant on the dihedral angle according to the well-known Karplus relationship, one would expect the ${ }^{3} J(\mathrm{C}, \mathrm{P})$ of the carbon in the trans arrangement to the phosphorus atom to evince larger splitting than the other arranged in the cis arrangement. Thus, ${ }^{3} J(\mathrm{C} 2$ ', $\mathrm{P})>{ }^{3} J\left(\mathrm{C}^{\prime}, \mathrm{P}\right)$ in rotamer $\mathrm{A}$ and ${ }^{3} J\left(\mathrm{C}^{\prime}, \mathrm{P}\right)>{ }^{3} J\left(\mathrm{C} 2^{\prime}, \mathrm{P}\right)$ in rotamer $\mathrm{B}$ should be observed. In order to support this assumption, we calculated ${ }^{3} J(\mathrm{C}, \mathrm{P})$ of the most stable conformers (see the chapter Conformational analysis) of the adenine derivatives $\mathbf{1 3}$ and $\mathbf{1 4}$ for both A and B rotamers using the DFT B3LYP/6-31++G* method. The results summarized in Table 1 show a good agreement of the calculated and experimental values, confirming correct assignment of the rotamers (Figure 10).

\begin{tabular}{|c|c|c|}
\hline Rotamer & ${ }^{3} J(C 2, P)$ & ${ }^{3} J(C 5, P)$ \\
\hline $13 A$ & $4.6(3.8)$ & $0(-0.8)$ \\
\hline 13B & $0(-0.3)$ & $4.9(4.8)$ \\
\hline $14 A$ & $4.5(4.2)$ & $0(-0.8)$ \\
\hline 14B & $0(-0.3)$ & $4.9(4.8)$ \\
\hline
\end{tabular}

\section{Conformational analysis}

The geometry of the pyrrolidine ring in the compounds studied can occupy various envelope (E) and twisted (T) conformations as depicted in Figure 11. The particular conformation is

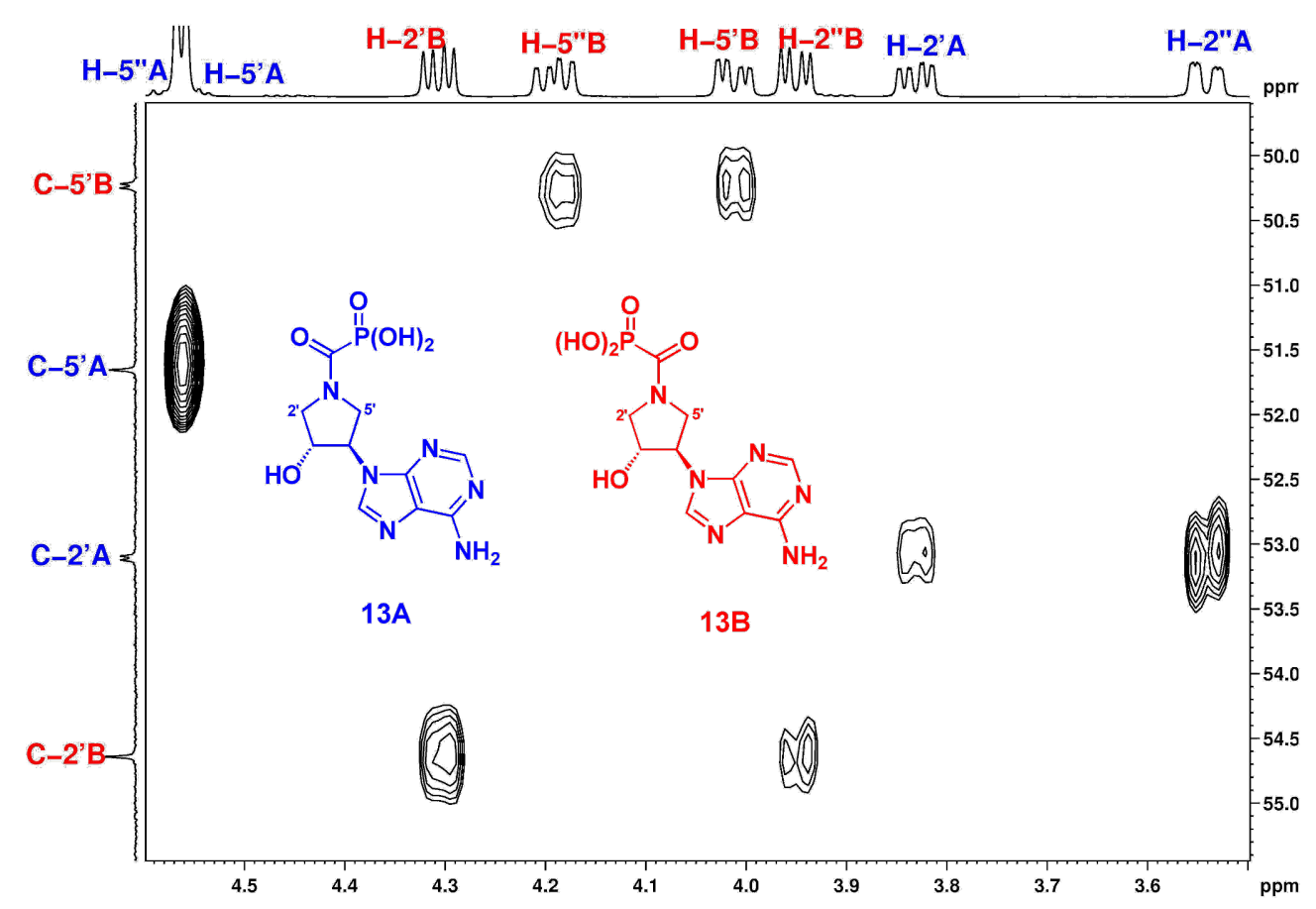

Figure 10: A part of the $H, C-H S Q C$ spectrum of derivative 13, showing the assignment of rotamers $A$ and $B$. 


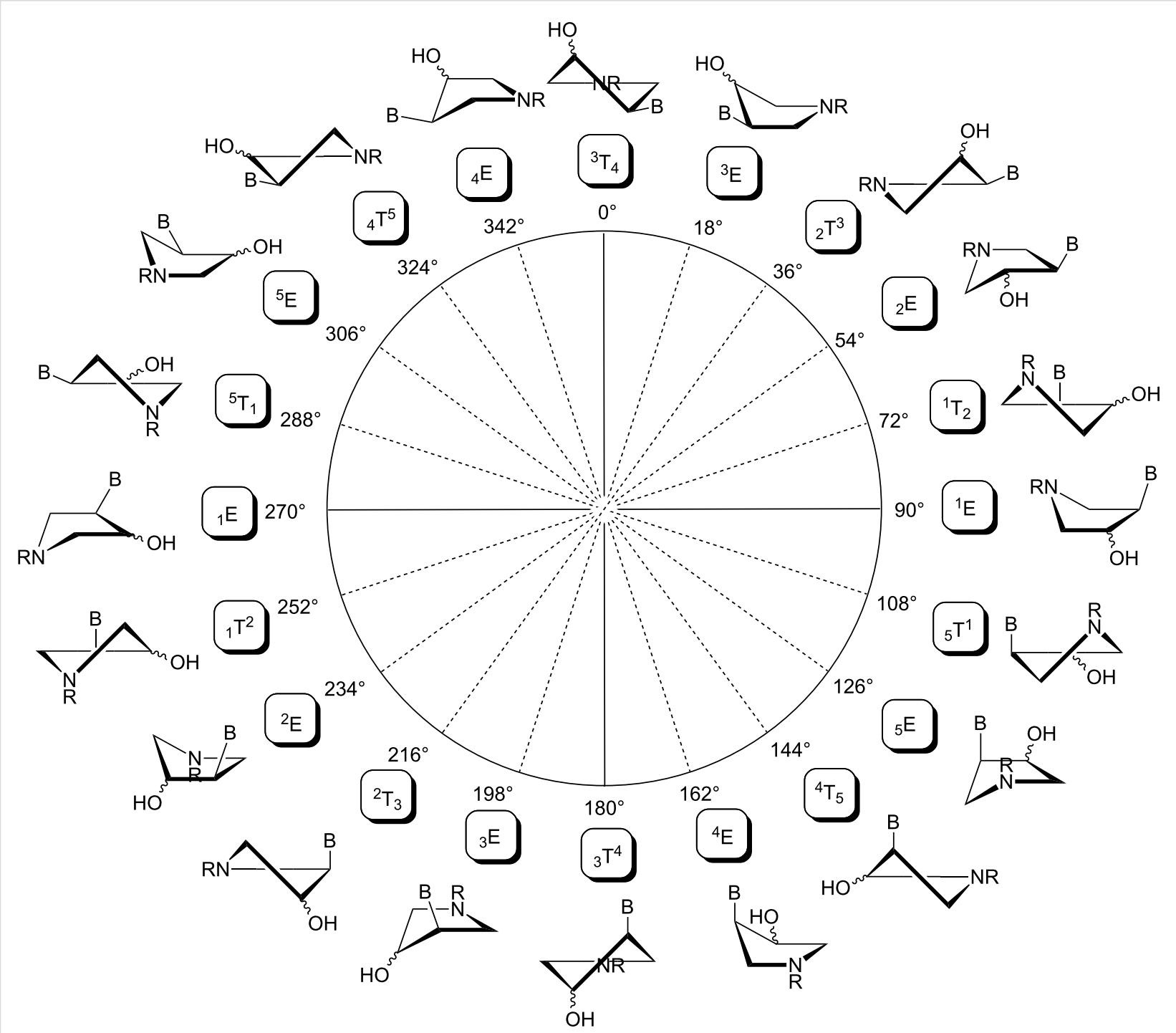

Figure 11: The pseudorotation pathway of the pyrrolidine ring in the compounds studied. The sign B stands for a nucleobase (thymin-1-yl or adenin$9-\mathrm{yl}$ ) and R means a phosphonomethyl or phosphonoformyl moiety.

described by two pseudorotation parameters: by the phase angle $(P)$ and by the maximum puckering amplitude $\left(\Phi_{\max }\right)[9]$. The phase angle is a periodic variable indicating which ring atoms are situated outside the ring plane and can reach $0^{\circ}-360^{\circ}$. The maximum puckering amplitude describes the degree of distortion of the five-membered ring out of the plane and its value is usually in the range of $35^{\circ}-45^{\circ}$.

Conformational analysis using experimental vicinal ${ }^{1} \mathrm{H}-{ }^{1} \mathrm{H}$ scalar coupling constants $\left({ }^{3} J_{\mathrm{HH}}\right)$ together with PSEUROTbased programs is aimed at fitting the calculated ${ }^{3} J_{\mathrm{HH}}$ to experimental values assuming a two-state conformation equilibrium. In this study, we used the Matlab Pseudorotation GUI program [12] to perform this task. The program requires several input parameters that include experimental ${ }^{3} J_{\mathrm{HH}}$ and constants $\mathrm{A}$ and
B, describing the relation between exocyclic $\Phi_{\text {exo }}$ (related to ${ }^{3} J_{\mathrm{HH}}$ ) and endocyclic $\Phi_{\text {endo }}$ (related to $P$ and $\Phi_{\max }$ ) dihedral angles $\left(\Phi_{\text {exo }}=\mathrm{A} \Phi_{\text {endo }}+\right.$ B).

The values of ${ }^{3} J_{\mathrm{HH}}$ (Table 2) were extracted from the ${ }^{1} \mathrm{H}$ NMR spectra, in which the signals were stereospecifically assigned based on ROESY cross-peaks as demonstrated on the example of compound 14 in Figure 12.

The parameters A and B for the five-membered ribose and deoxyribose ring had been traditionally obtained from X-ray data [18]. In the case of a five-membered ring for which X-ray data are not available, DFT-optimized geometries of a number of conformations are used [19]. This molecular modeling approach was also employed in the case of the studied com- 


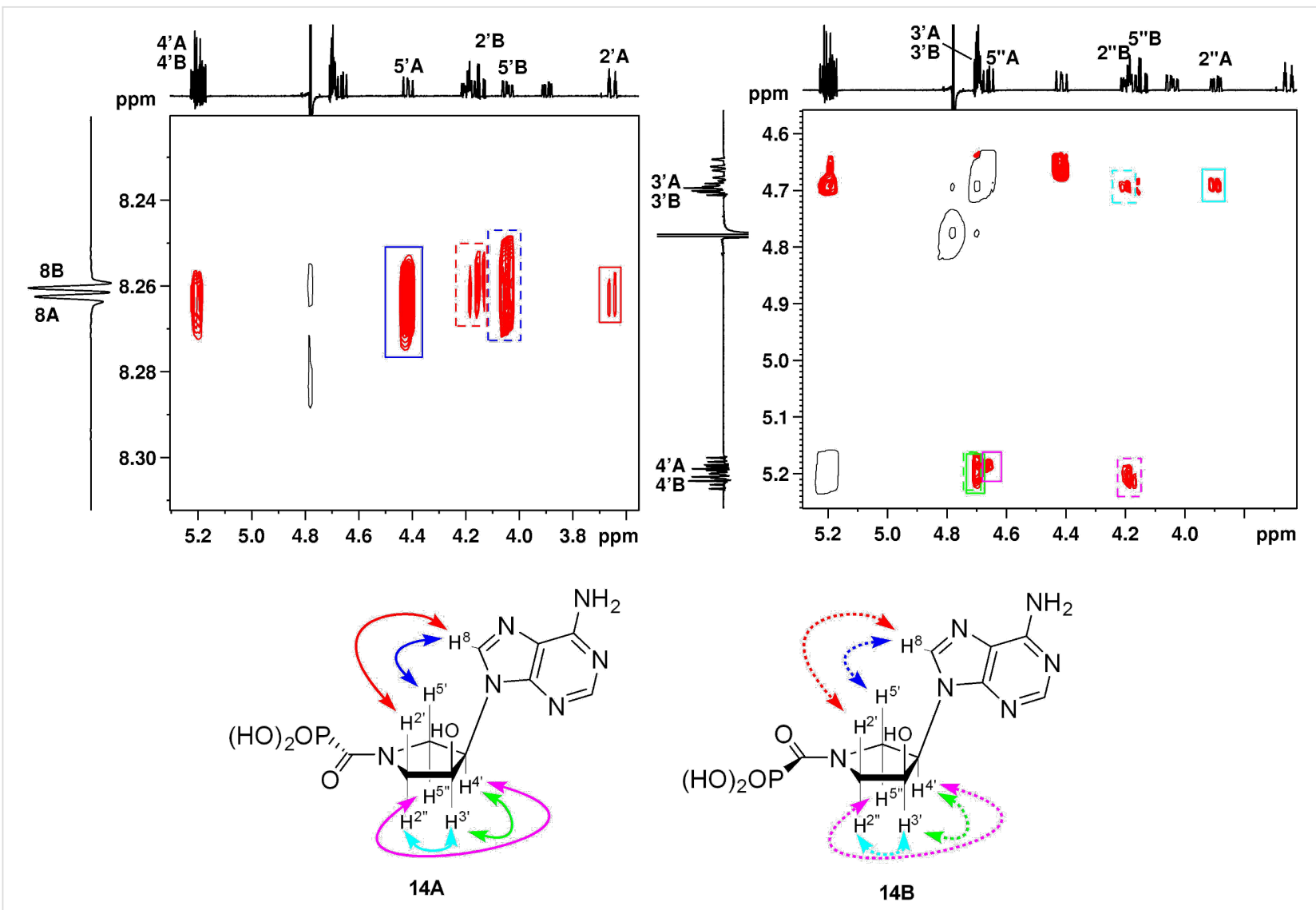

Figure 12: An example of the stereospecific assignment of pyrrolidine-ring protons of 14 in the $H, H-R O E S Y$ spectrum.

Table 2: The ${ }^{3} J_{\mathrm{HH}}$ of the pyrrolidine-ring protons used in the conformational analysis.

\begin{tabular}{cccccc} 
& $2^{\prime}, 3^{\prime}$ & $2^{\prime \prime}, 3^{\prime}$ & $3^{\prime}, 4^{\prime}$ & $4^{\prime}, 5^{\prime}$ & $4^{\prime}, 5^{\prime \prime}$ \\
\hline 7 & 6.9 & 6.4 & 4.1 & 5.6 & 9.1 \\
$\mathbf{8}$ & 2.0 & 5.2 & 6.0 & 6.9 & 9.4 \\
$\mathbf{9}$ & 6.5 & 5.1 & 3.0 & 4.4 & 7.3 \\
10 & 3.5 & 6.1 & 6.2 & 5.0 & 7.9 \\
11A & 6.8 & 4.8 & 5.4 & 6.2 & 7.7 \\
11B & 6.1 & 5.7 & 5.5 & 6.1 & 8.5 \\
12A & 2.1 & 5.2 & 4.5 & 9.5 & 8.1 \\
12B & 3.3 & 4.8 & 4.6 & 8.5 & 8.5 \\
13A & 6.1 & 4.1 & 4.5 & 5.6 & 6.3 \\
13B & 5.8 & 5.2 & 5.3 & 5.5 & 7.8 \\
14A & 2.1 & 5.1 & 4.2 & 9.2 & 7.6 \\
14B & 3.5 & 4.6 & 4.3 & 8.3 & 8.2
\end{tabular}

pounds 7-14. We performed the ring parameterization for adenine derivatives 9, 10, 13 and $\mathbf{1 4}$ (see Supporting Information File 1 for details) and assumed that replacing adenine for thymine as a nucleobase would not dramatically affect the constants $\mathrm{A}$ and $\mathrm{B}$.
The results of the conformational analysis obtained using the Matlab Pseudorotation GUI program are summarized in Table 3. Instead of presenting the pseudorotation parameters $P$ and $\Phi_{\max }$ in numbers, we rather present the pseudorotation maps generated by the program in which the contour plots indicate the root-mean-square-deviation between the fitted and experimental ${ }^{3} J_{\mathrm{HH}}$. These conformation maps provide a more realistic view of the conformational behavior of compounds 7-14 than a single numeric value for $P$ and $\Phi_{\max }$.

The pseudorotation maps reveal the effect of the substitution of the pyrrolidine ring on its conformation. The conformation of phosphonomethyl derivatives 7 and 9 with trans configuration on 3' and 4' carbon atoms tends to occupy mainly ( $\sim 60 \%)$ the ${ }^{1} \mathrm{~T}_{2}$ or ${ }^{1} \mathrm{E}$ conformation in an equilibrium with the less populated $(\sim 40 \%){ }_{1} \mathrm{E}$ conformer. This equilibrium is significantly shifted in the case of cis derivatives $\mathbf{8}$ and $\mathbf{1 0}$ towards the ${ }_{2} \mathrm{~T}^{3}$ conformation $(>80 \%)$ due to the steric hindrance of 3 ' and 4 ' substituents, where the nucleobase occupies predominantly the pseudo-equatorial position. There is an obvious contrast between minor conformations of $\mathbf{8}$ and 10, which might be caused by hydrogen bonding between the 3 '-OH group and the 4'-nucleobase substituent. 
A similar effect in the conformer populations was observed for phosphonoformyl derivatives. While trans derivatives 11 and 13 exist as an about 1:1 equilibrium mixture of ${ }^{3} \mathrm{~T}_{4}$ and ${ }_{3} \mathrm{~T}^{4}$ conformations, cis derivatives $\mathbf{1 2}$ and $\mathbf{1 4}$ prefer $(>80 \%)$ the ${ }^{3} \mathrm{~T}_{4}$ conformation. The orientation of the phosphonoformyl moiety (rotamers A and B) has a negligible effect on the conformation of the pyrrolidine ring; therefore, only conformation maps for rotamer A are presented in Table 3. The effect of the alkylation

Table 3: The results of the conformational analysis.

Analog Pseudorotation mapa

7

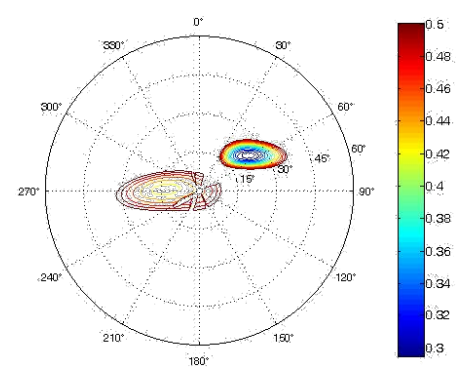

8

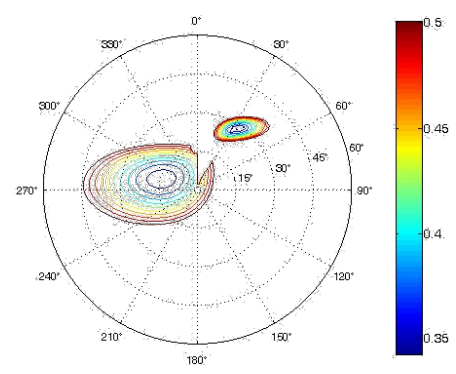

9

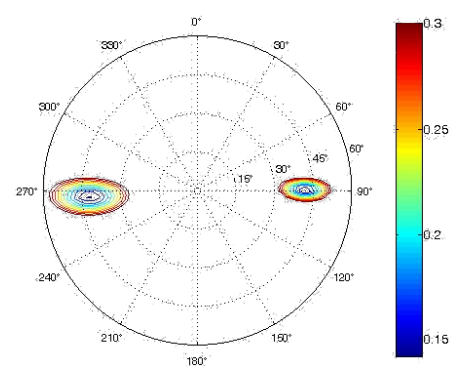

10

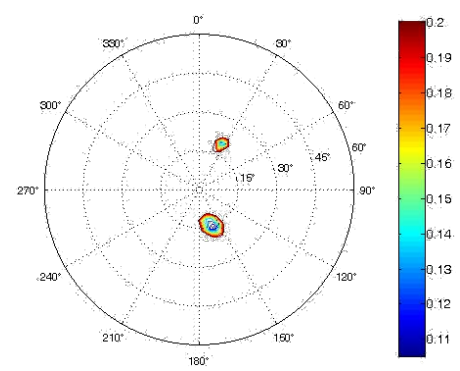

Conformer population ${ }^{b}$
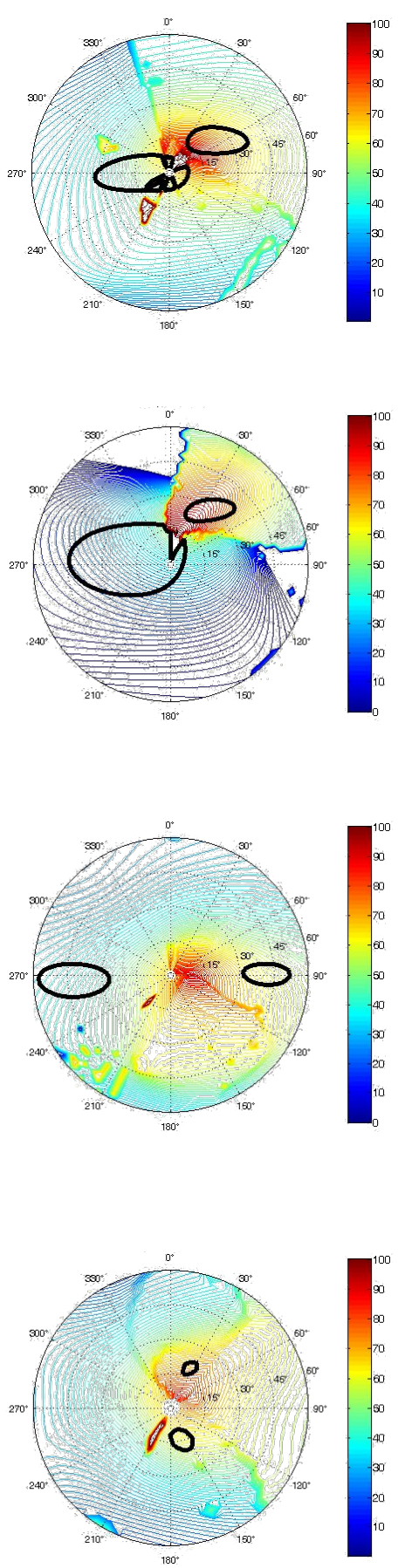

Conformation preferences ${ }^{c}$
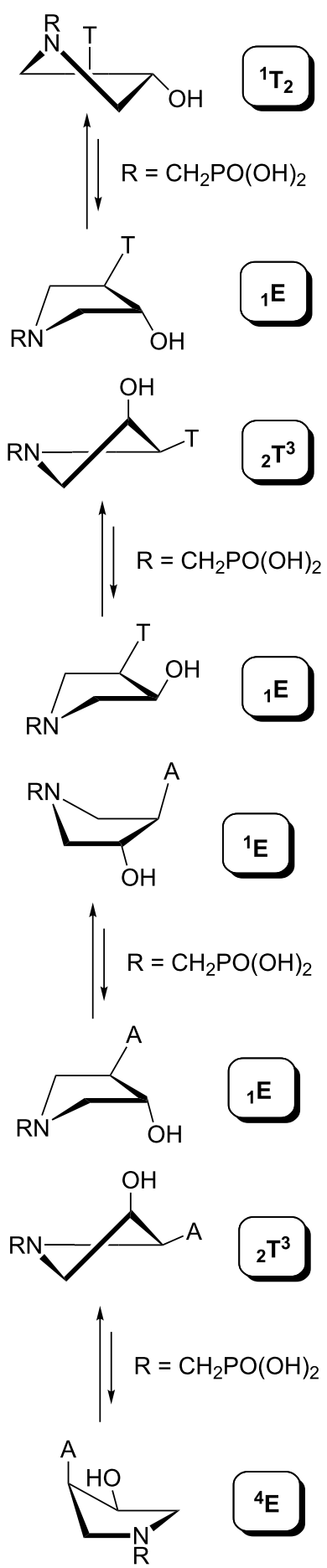
$11 \mathrm{~A}$

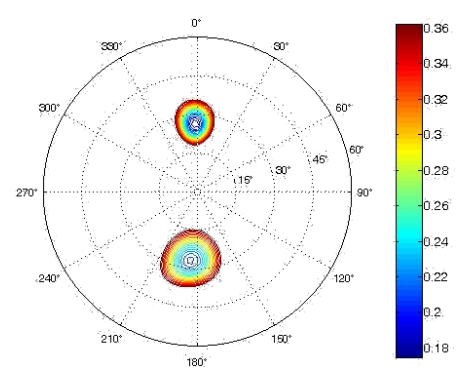

$12 \mathrm{~A}$

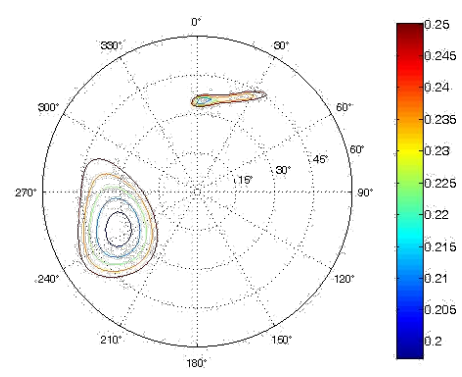

13A

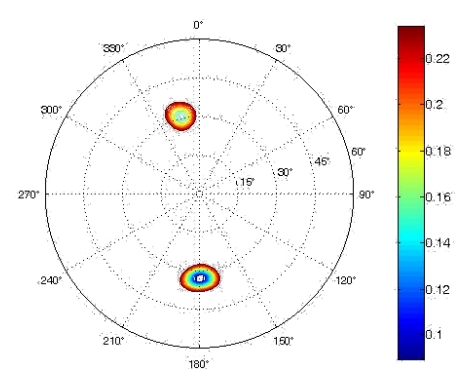

14A

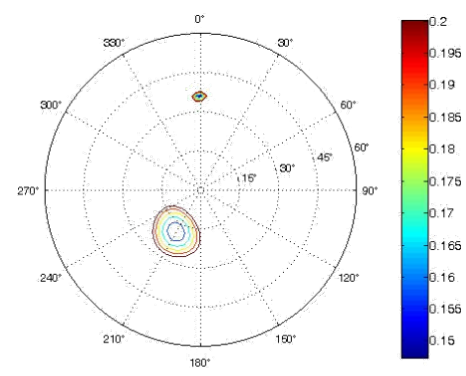

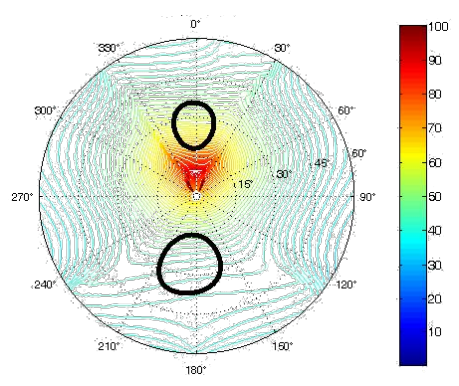
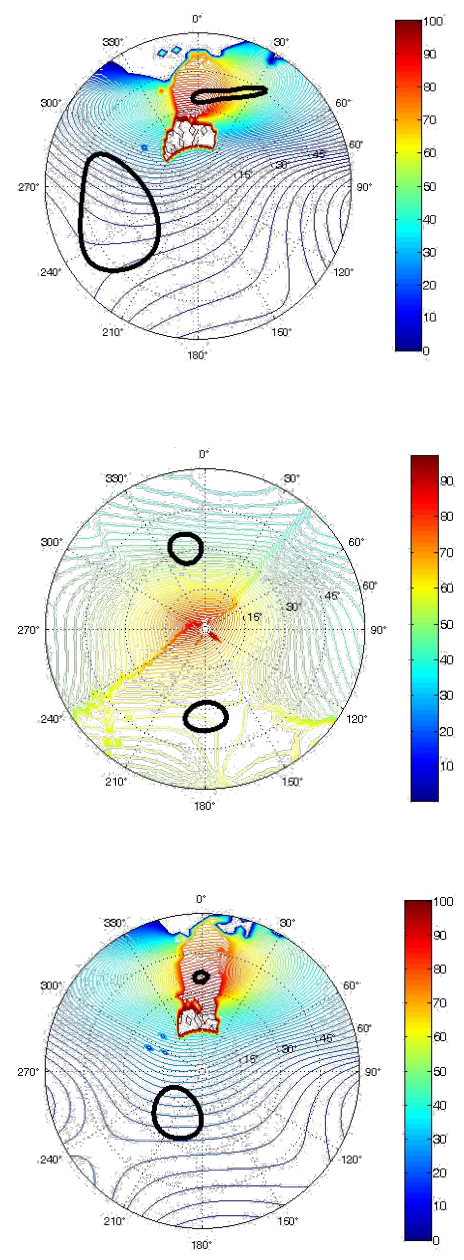
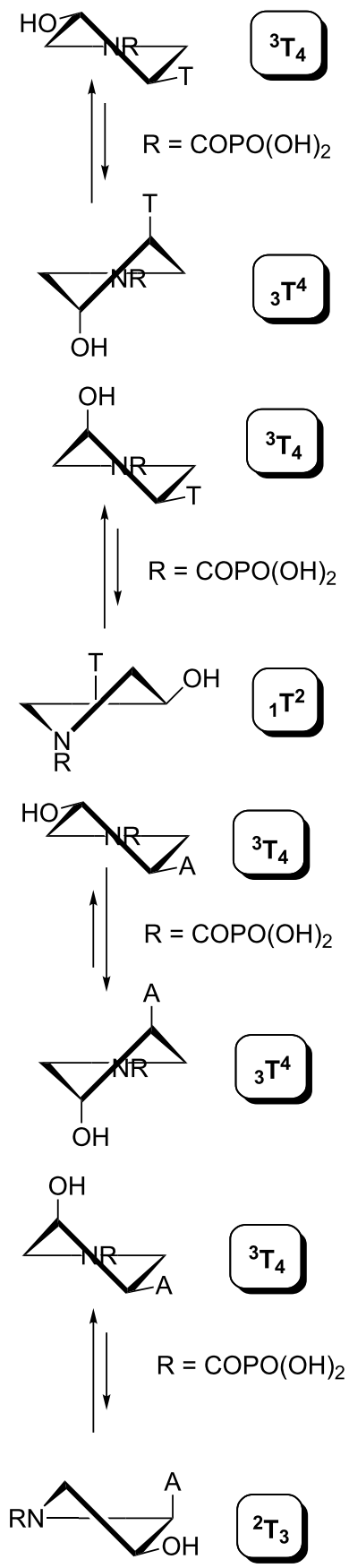

aThe contour lines indicate the total RMSD of the fit. ${ }^{b}$ The contour lines indicate the percentage of the conformation present in the best fit. The thicker black line is the outer contour line of the two dominant conformations from the second column of the table. ${ }^{\mathrm{C}} \mathrm{A}$ graphical illustration of the conformations obtained from the pseudorotation maps.

or acylation of the pyrrolidine nitrogen is also fairly visible in the pseudorotation maps. Phosphonoformyl derivatives 11-14 keep the conformation of the pyrrolidine ring in narrow northern $\left(P \sim 0^{\circ}\right)$ and southern $\left(\mathrm{P} \sim 180^{\circ}\right)$ regions, which arises from the plane arrangement of the $\mathrm{C} 2^{\prime}-\mathrm{N} 1$ '- ${ }^{\prime} 5^{\prime}$ fragment of the pyrrolidine ring (minor conformers of cis derivatives 12A and $14 \mathrm{~A}$ do not follow this trend). In contrast to that, the conformation of the pyrrolidine ring in phosphonomethyl derivatives 7-10 is more flexible and rather occupies the eastern and western segments of the pseudorotation wheel, reacting sensi- 
tively to the hydrogen bonding between the 3'-OH group and the 4'-nucleobase substituent.

In order to supplement our experimental observation, we calculated the energy profile of the five-membered pyrrolidine ring pseudorotation for adenine derivatives 9 and 13. We generated 20 conformers covering the whole pseudorotation pathway in 18-degree steps with constant maximum puckering amplitude of 40 degrees. For each conformer, the endocyclic torsion angles $\Phi_{0}$ and $\Phi_{3}$ were kept fixed and the geometry of the molecule was optimized using the DFT B3LYP/6-31G* method in vacuo. Predominant conformations can be found as the energy minima by plotting the calculated energy against phase angle $P$ (Figure 13). The curves in Figure 13 proved a two-state equilibrium used as a prerequisite in PSEUROT-based programs and known for furanose conformation in natural nucleosides and nucleotides.

The two energy minima were then fully optimized by B3LYP/ $6-31++\mathrm{G}^{*}$ in water (the CPCM model). The optimized conformations were compared with those obtained by conformational

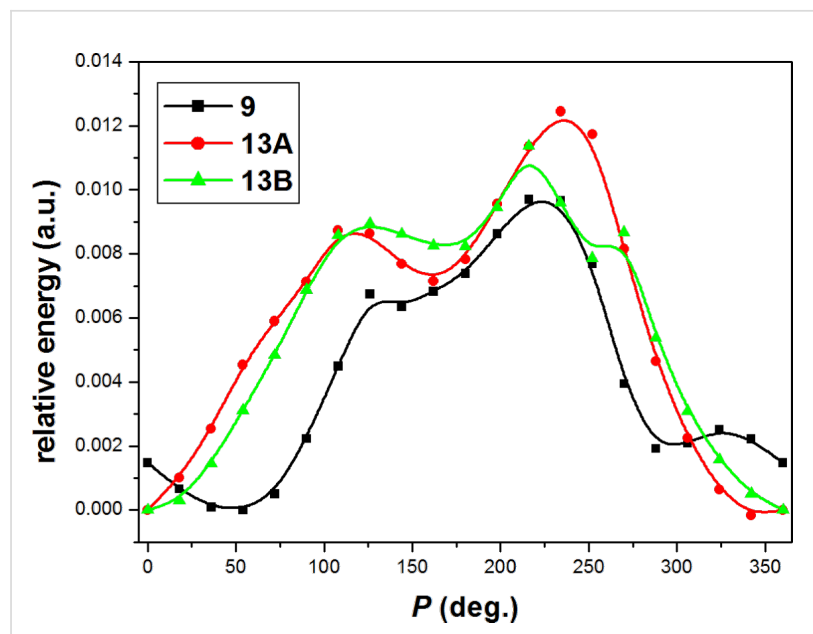

Figure 13: The energy profile of the five-membered pyrrolidine ring pseudorotation for adenine derivatives 9 and 13 .

analysis using ${ }^{3} J_{\mathrm{HH}}$ and the results showed a good agreement of the molecular modeling and the experiment (cf. Table 3 and Figure 14).

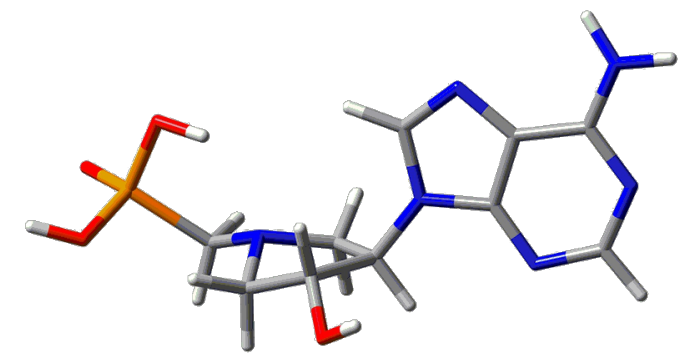

$9\left(P=72^{\circ}, \phi_{\max }=44^{\circ}\right)$

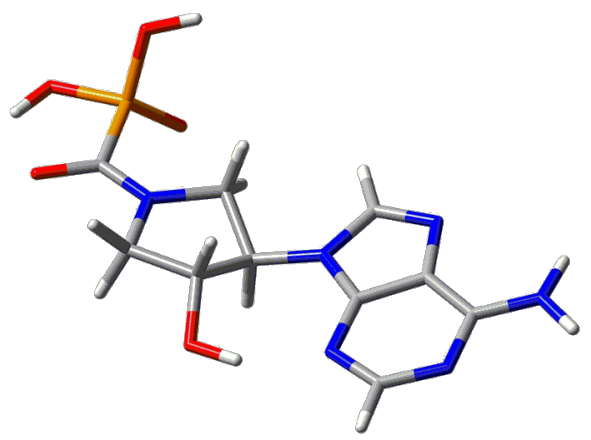

13A $\left(P=344^{\circ}, \phi_{\max }=38^{\circ}\right)$

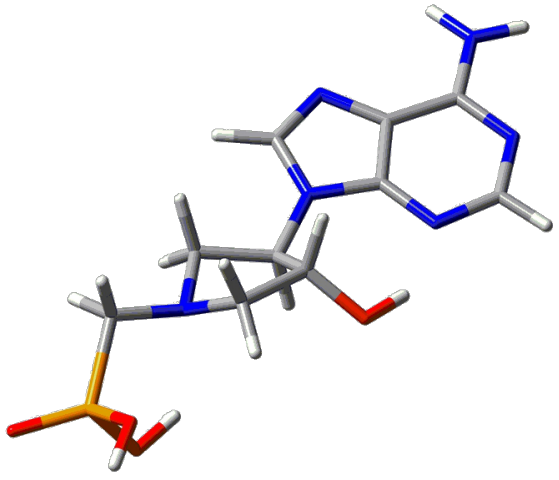

$9\left(P=299^{\circ}, \phi_{\max }=45^{\circ}\right)$

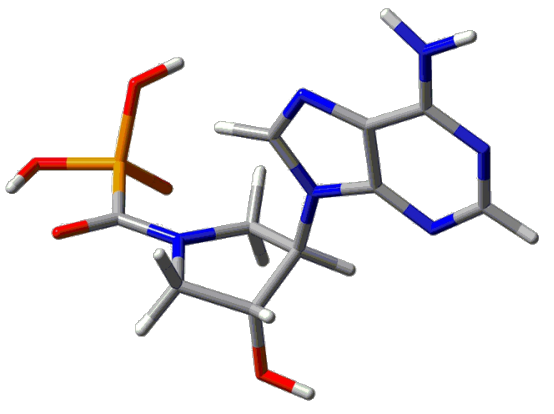

13A $\left(P=174^{\circ}, \phi_{\max }=36^{\circ}\right)$

Figure 14: The most stable conformations of adenine derivatives 9 and $13 A$ calculated by the B3LYP/6-31++G* method in water (CPCM). 


\section{Conclusion}

In summary, we presented an NMR and DFT conformational analysis of pyrrolidine nucleotide analogs bearing phosphonomethyl or phosphonoformyl substituents attached to the pyrrolidine nitrogen atom. The mode of the phosphonate moiety attachment to the pyrrolidine ring results in tuning the conformation of the five-membered pyrrolidine ring over the whole pseudorotation wheel. While phosphonoformyl derivatives 11-14 keep the conformation of the pyrrolidine ring in narrow northern $\left(P \sim 0^{\circ}\right)$ and southern $\left(P \sim 180^{\circ}\right)$ regions, which arises from the plane arrangement of the $\mathrm{C} 2^{\prime}-\mathrm{N} 1$ ' $-\mathrm{C} 5$ ' fragment of the pyrrolidine ring, the conformation of phosphonomethyl derivatives 7-10 is more flexible and rather occupies the eastern and western segment of the pseudorotation wheel. In general, this simple yet effective tuning of the pyrrolidine-ring conformation can be used for a number of other pyrrolidine derivatives.

\section{Experimental Chemistry}

Phosphonoalkyl derivatives 7-10 were prepared according to the procedures described in [20] while thymine carbonylphosphonic acids 11 and 12 were prepared according to the procedures described in [4]. Unless stated otherwise, all solvents used were anhydrous. TLC was performed on TLC plates precoated with silica gel (silica gel/TLC-cards, UV 254, Merck). The compounds were detected using UV light (254 nm), by spraying with $1 \%$ ethanolic solution of ninhydrine to visualize amines, or by spraying with a $1 \%$ solution of 4-(4-nitrobenzyl)pyridine in ethanol, followed by heating and treatment with gaseous ammonia (for the detection of alkylating agents, such as dialkyl phosphonates; blue color). The course of the reactions and the purity of the prepared compounds were determined by LC-MS using a Waters AutoPurification System with a 2545 Quaternary Gradient Module and a 3100 Single Quadrupole Mass Detector using a Luna C18 column $(100 \times 4.6 \mathrm{~mm}, 3 \mu \mathrm{m}$, Phenomenex $)$ at a flow rate of $1 \mathrm{~mL} / \mathrm{min}$. The following mobile phase was used, where A, B, and $\mathrm{C}$ represent $50 \mathrm{mM} \mathrm{NH}_{4} \mathrm{HCO}_{3}, 50 \mathrm{mM} \mathrm{NH}_{4} \mathrm{HCO}_{3}$ in $50 \%$ aq $\mathrm{CH}_{3} \mathrm{CN}$, and $\mathrm{CH}_{3} \mathrm{CN}$, respectively: $\mathrm{A} \rightarrow \mathrm{B}$ over $10 \mathrm{~min}$, $\mathrm{B} \rightarrow \mathrm{C}$ over $10 \mathrm{~min}$ and $\mathrm{C}$ for $5 \mathrm{~min}$. Preparative RP HPLC was performed on an LC5000 Liquid Chromatograph (INGOSPIKRON, CR) using a Luna C18 (2) column $(250 \times 21.2 \mathrm{~mm}$, $5 \mu \mathrm{m})$ at a flow rate of $10 \mathrm{~mL} / \mathrm{min}$. A gradient elution of methanol in $\mathrm{pH} 7.50 .1 \mathrm{M}$ TEAB (A, 0.1 M TEAB; B, 0.1 M TEAB in 50\% aq methanol; $\mathrm{C}$, methanol) was used. All final compounds were lyophilized. Mass spectra were collected on an LTQ Orbitrap XL (Thermo Fisher Scientific) using ESI ionization. The $\mathrm{pD}$ titrations were performed on $\mathrm{pH}$ meter IQ150 Scientific Instruments equipped with a $\mathrm{pH}$ probe $\mathrm{PH} 47-\mathrm{SS}$. NMR spectra were acquired in $\mathrm{D}_{2} \mathrm{O}$ on a Bruker AVANCE 600 $\left({ }^{1} \mathrm{H}\right.$ at $600.1 \mathrm{MHz}$ and ${ }^{13} \mathrm{C}$ at $\left.150.9 \mathrm{MHz}\right)$, Bruker AVANCE $500\left({ }^{1} \mathrm{H}\right.$ at $499.8 \mathrm{MHz},{ }^{13} \mathrm{C}$ at $125.7 \mathrm{MHz}$ and ${ }^{31} \mathrm{P}$ at $202.3 \mathrm{MHz})$ and/or Bruker AVANCE $400\left({ }^{1} \mathrm{H}\right.$ at $400.0 \mathrm{MHz}$, ${ }^{13} \mathrm{C}$ at $100.6 \mathrm{MHz}$ and ${ }^{31} \mathrm{P}$ at $162.0 \mathrm{MHz}$ ) NMR spectrometers. Chemical shifts (in ppm, $\delta$ scale) were referenced to the 1,4 dioxane signal (3.75 ppm for ${ }^{1} \mathrm{H}$ and $69.3 \mathrm{ppm}$ for $\left.{ }^{13} \mathrm{C}\right)$ as an internal or external standard. ${ }^{31} \mathrm{P}$ NMR spectra were referenced to $\mathrm{H}_{3} \mathrm{PO}_{4}(0 \mathrm{ppm})$ as an external standard. Coupling constants $(J)$ are given in $\mathrm{Hz}$. The complete assignment of ${ }^{1} \mathrm{H}$ and ${ }^{13} \mathrm{C}$ signals was performed by an analysis of the correlated homonuclear H,H-COSY, H,H-ROESY and heteronuclear H,C-HSQC and $\mathrm{H}, \mathrm{C}-\mathrm{HMBC}$ spectra.

\section{Calculations}

All calculations were carried out using the Gaussian 09 software package [21]. DFT calculations were performed using Becke3-LYP $[22,23]$ with $6-31 \mathrm{G}^{*}$ basis set for a fixed conformation geometry in the calculation of the energy profile (Figure 13 ) or $6-31++\mathrm{G}^{*}$ basis set for full geometry optimizations. The full geometry optimizations were carried out using conductor-like polarizable continuum model (CPCM) [24].

\section{General method 1: Synthesis of phosphonoacyl derivatives (13 and 14)}

General method 1 followed the similar procedure described previously [6]. The mixture of pyrrolidine nucleosides 15a,b [15] (1 mmol) and diisopropyl phenylphosphonoformiate (1.2 mmol) in DMF $(10 \mathrm{~mL})$ was stirred at $80{ }^{\circ} \mathrm{C}$ for $1 \mathrm{~h}$ (the course of the reaction was followed by TLC using the solvent system $\mathrm{H} 1$ (EtOAc/acetone/EtOH/ $\mathrm{H}_{2} \mathrm{O} 4: 1: 1: 1$ ) or LC-MS). The reaction mixture was concentrated in vacuo and the intermediate 18a,b was obtained in a pure form by chromatography on silica gel using a linear gradient of $\mathrm{H} 1$ in ethyl acetate. The intermediate 18a,b $(1 \mathrm{mmol})$ was dissolved in acetonitrile $(10 \mathrm{~mL})$ and bromotrimethylsilane $(5 \mathrm{mmol})$ was added under argon atmosphere. The reaction mixture was stirred overnight at room temperature under argon atmosphere. The reaction mixture was concentrated in vacuo, dissolved in $0.5 \mathrm{M}$ aqueous TEAB $(5 \mathrm{~mL})$ and evaporated. The final product was obtained by preparative HPLC, converted to its sodium salt by passing through a column of Dowex 50 in a $\mathrm{Na}^{+}$form $(10 \mathrm{~mL} / \mathrm{mmol})$ and lyophilized from water.

\section{$(3 R, 4 R)-4-($ Adenin-9-yl)-3-hydroxypyrrolidin-1-N- ylcarbonylphosphonic acid (13)}

The title compound was prepared according to general method 1 from pyrrolidine nucleoside $15 \mathrm{a}(0.08 \mathrm{~g}, 0.36 \mathrm{mmol})$ in $56 \%$ overall yield $(75.2 \mathrm{mg}, 0.2 \mathrm{mmol})$ in the form of a white amorphous solid. HRMS-ESI: $[\mathrm{M}+\mathrm{H}]^{+}$calcd for $\mathrm{C}_{10} \mathrm{H}_{13} \mathrm{O}_{5} \mathrm{~N}_{6} \mathrm{NaP}$, 351.05736; found, 351.05728. The NMR spectra showed a 10:11 mixture of rotamers A:B. Rotamer A: ${ }^{1} \mathrm{H}$ NMR 
(600.1 MHz, $\left.\mathrm{D}_{2} \mathrm{O}, T=25^{\circ} \mathrm{C}, \mathrm{pD}=6.1\right) 3.54\left(\mathrm{dddd}, J_{\mathrm{gem}}=\right.$ $\left.13.6, J_{2^{\prime \prime}, 3^{\prime}}=4.1, J_{\mathrm{H}, \mathrm{P}}=1.9, J_{2^{\prime \prime}, 5^{\prime \prime}}=0.9,1 \mathrm{H}, \mathrm{H}-2^{\prime \prime}\right), 3.83(\mathrm{ddd}$, $\left.J_{\text {gem }}=13.6, J_{2^{\prime}, 3^{\prime}}=6.1, J_{\mathrm{H}, \mathrm{P}}=1.9,1 \mathrm{H}, \mathrm{H}-2^{\prime}\right), 4.55\left(\mathrm{ddd}, J_{\mathrm{gem}}=\right.$ $\left.13.0, J_{5^{\prime}, 4^{\prime}}=5.6, J_{5^{\prime}, 3^{\prime}}=0.9,1 \mathrm{H}, \mathrm{H}-5^{\prime}\right), 4.57\left(\mathrm{ddd}, J_{\text {gem }}=13.0\right.$, $\left.J_{5^{\prime \prime}, 4^{\prime}}=6.3, J_{5^{\prime \prime}, 2^{\prime \prime}}=0.9,1 \mathrm{H}, \mathrm{H}-5^{\prime \prime}\right), 4.73\left(\mathrm{dddd}, J_{3^{\prime}, 2^{\prime}}=6.1, J_{3^{\prime}, 4^{\prime}}\right.$ $\left.=4.5, J_{3^{\prime}, 2^{\prime \prime}}=4.1, J_{3^{\prime}, 5^{\prime}}=0.9,1 \mathrm{H}, \mathrm{H}-3^{\prime}\right), 5.01\left(\mathrm{ddd}, J_{4^{\prime}, 5^{\prime \prime}}=6.3\right.$, $\left.J_{4^{\prime}, 5^{\prime}}=5.6, J_{4^{\prime}, 3^{\prime}}=4.5,1 \mathrm{H}, \mathrm{H}-4^{\prime}\right), 8.134(\mathrm{~s}, 1 \mathrm{H}, \mathrm{H}-8), 8.151(\mathrm{~s}$, $1 \mathrm{H}, \mathrm{H}-2) ;{ }^{13} \mathrm{C}$ NMR $\left(150.9 \mathrm{MHz}, \mathrm{D}_{2} \mathrm{O}, T=25^{\circ} \mathrm{C}, \mathrm{pD}=6.1\right)$ $51.65\left(\mathrm{C}-5^{\prime}\right), 53.11\left(\mathrm{~d}, J_{\mathrm{C}, \mathrm{P}}=4.6, \mathrm{C}-2^{\prime}\right), 62.87\left(\mathrm{C}-4{ }^{\prime}\right), 73.75$ (C-3'), 121.29 (C-5), 142.56 (C-8), 151.58 (C-4), 154.92 (C-2), $157.98(\mathrm{C}-6), 179.15\left(\mathrm{~d}, J_{\mathrm{C}, \mathrm{P}}=197.5, \mathrm{P}-\mathrm{CO}\right) ;{ }^{31} \mathrm{P}\{1 \mathrm{H}\} \mathrm{NMR}$ (202.3 MHz, $\left.\mathrm{D}_{2} \mathrm{O}, T=25{ }^{\circ} \mathrm{C}, \mathrm{pD}=6.1\right)-2.25$. Rotamer $\mathrm{B}$ : ${ }^{1} \mathrm{H}$ NMR (600.1 MHz, $\left.\mathrm{D}_{2} \mathrm{O}, T=25{ }^{\circ} \mathrm{C}, \mathrm{pD}=6.1\right) 3.95(\mathrm{dd}$, $\left.J_{\text {gem }}=12.6, J_{2^{\prime \prime}, 3^{\prime}}=5.2,1 \mathrm{H}, \mathrm{H}-2^{\prime \prime}\right), 4.01\left(\mathrm{ddd}, J_{\text {gem }}=13.6, J_{5^{\prime}, 4^{\prime}}\right.$ $\left.=5.5, J_{\mathrm{H}, \mathrm{P}}=1.9,1 \mathrm{H}, \mathrm{H}-5^{\prime}\right), 4.19\left(\mathrm{ddd}, J_{\text {gem }}=13.6, J_{5^{\prime \prime}, 4^{\prime}}=7.8\right.$, $\left.J_{\mathrm{H}, \mathrm{P}}=2.0,1 \mathrm{H}, \mathrm{H}-5^{\prime \prime}\right), 4.31\left(\mathrm{ddd}, J_{\mathrm{gem}}=12.6, J_{2^{\prime}, 3^{\prime}}=5.8, J_{2^{\prime}, 5^{\prime}}=\right.$ $\left.0.8,1 \mathrm{H}, \mathrm{H}-2^{\prime}\right), 4.76\left(\mathrm{ddd}, J_{3^{\prime}, 2^{\prime}}=5.8, J_{3^{\prime}, 4^{\prime}}=5.3, J_{3^{\prime}, 2^{\prime \prime}}=5.2,1 \mathrm{H}\right.$, H-3'), 4.99 (ddd, $\left.J_{4^{\prime}, 5^{\prime \prime}}=7.8, J_{4^{\prime}, 5^{\prime}}=5.5, J_{4^{\prime}, 3^{\prime}}=5.3,1 \mathrm{H}, \mathrm{H}-4^{\prime}\right)$, 8.130 (s, 1H, H-8), 8.149 (s, 1H, H-2); ${ }^{13} \mathrm{C}$ NMR (150.9 MHz, $\left.\mathrm{D}_{2} \mathrm{O}, T=25^{\circ} \mathrm{C}, \mathrm{pD}=6.1\right) 50.23\left(\mathrm{~d}, J_{\mathrm{C}, \mathrm{P}}=4.9, \mathrm{C}-5^{\prime}\right), 54.64$ (C-2'), 60.88 (C-4'), 75.44 (C-3'), 121.29 (C-5), 142.73 (C-8), $151.62(\mathrm{C}-4), 154.95$ (C-2), $158.00(\mathrm{C}-6), 179.24$ (d, $J_{\mathrm{C}, \mathrm{P}}=$ 197.0, P-CO); ${ }^{31} \mathrm{P}\{1 \mathrm{H}\}$ NMR (202.3 MHz, $\mathrm{D}_{2} \mathrm{O}, T=25^{\circ} \mathrm{C}, \mathrm{pD}$ $=6.1)-2.23$.

\section{(3S,4R)-4-(Adenin-9-yl)-3-hydroxypyrrolidin-1-N-} ylcarbonylphosphonic acid (14)

The title compound was prepared according to general method 1 from pyrrolidine nucleoside $\mathbf{1 5 b}(0.19 \mathrm{~g}, 0.86 \mathrm{mmol})$ in $28 \%$ overall yield (91 mg, $0.25 \mathrm{mmol})$ in the form of a white amorphous solid. HRMS-ESI: $[\mathrm{M}+\mathrm{H}]^{+}$calcd for $\mathrm{C}_{10} \mathrm{H}_{13} \mathrm{O}_{5} \mathrm{~N}_{6} \mathrm{NaP}$, 351.05736; found, 351.05773. The NMR spectra showed a 10:11 mixture of rotamers A:B. Rotamer A: ${ }^{1} \mathrm{H}$ NMR (600.1 MHz, $\left.\mathrm{D}_{2} \mathrm{O}, T=25^{\circ} \mathrm{C}, \mathrm{pD}=5.9\right) 3.65\left(\mathrm{dt}, J_{\text {gem }}=13.7\right.$, $\left.J_{2^{\prime}, 3^{\prime}}=J_{\mathrm{H}, \mathrm{P}}=2.1,1 \mathrm{H}, \mathrm{H}-2^{\prime}\right), 3.90\left(\mathrm{ddd}, J_{\mathrm{gem}}=13.7, J_{2^{\prime \prime}, 3^{\prime}}=5.1\right.$, $\left.J_{\mathrm{H}, \mathrm{P}}=1.9,1 \mathrm{H}, \mathrm{H}-2^{\prime \prime}\right), 4.41\left(\mathrm{dd}, J_{\mathrm{gem}}=11.6, J_{5^{\prime}, 4^{\prime}}=9.2,1 \mathrm{H}\right.$, H-5'), 4.66 (dd, $\left.J_{\text {gem }}=11.6, J_{5^{\prime \prime}, 4^{\prime}}=7.6,1 \mathrm{H}, \mathrm{H}-5^{\prime \prime}\right), 4.693$ (ddd, $\left.J_{3^{\prime}, 2^{\prime \prime}}=5.1, J_{3^{\prime}, 4^{\prime}}=4.2, J_{3^{\prime}, 2^{\prime}}=2.1,1 \mathrm{H}, \mathrm{H}-3^{\prime}\right), 5.19\left(\mathrm{ddd}, J_{4^{\prime}, 5^{\prime}}=\right.$ $\left.9.2, J_{4^{\prime}, 5^{\prime \prime}}=7.6, J_{4^{\prime}, 3^{\prime}}=4.2,1 \mathrm{H}, \mathrm{H}-4^{\prime}\right), 8.158(\mathrm{~s}, 1 \mathrm{H}, \mathrm{H}-2), 8.262$ (s, $1 \mathrm{H}, \mathrm{H}-8) ;{ }^{13} \mathrm{C}$ NMR $\left(150.9 \mathrm{MHz}, \mathrm{D}_{2} \mathrm{O}, T=25^{\circ} \mathrm{C}, \mathrm{pD}=5.9\right)$ $50.18\left(\mathrm{C}-5^{\prime}\right), 54.30\left(\mathrm{~d}, J_{\mathrm{C}, \mathrm{P}}=4.5, \mathrm{C}-2^{\prime}\right), 58.95\left(\mathrm{C}-4^{\prime}\right), 70.35$ (C-3'), 120.80 (C-5), 143.65 (C-8), 151.93 (C-4), 154.89 (C-2), $157.95(\mathrm{C}-6), 178.88\left(\mathrm{~d}, J_{\mathrm{C}, \mathrm{P}}=198.3, \mathrm{P}-\mathrm{CO}\right) ;{ }^{31} \mathrm{P}\left\{{ }^{1} \mathrm{H}\right\} \mathrm{NMR}$ (202.3 MHz, $\left.\mathrm{D}_{2} \mathrm{O}, T=25{ }^{\circ} \mathrm{C}, \mathrm{pD}=5.9\right)-2.21$. Rotamer $\mathrm{B}$ : ${ }^{1} \mathrm{H}$ NMR (600.1 MHz, $\left.\mathrm{D}_{2} \mathrm{O}, T=25{ }^{\circ} \mathrm{C}, \mathrm{pD}=5.9\right) 4.04(\mathrm{ddd}$, $\left.J_{\text {gem }}=12.8, J_{5^{\prime}, 4^{\prime}}=8.3, J_{\mathrm{H}, \mathrm{P}}=1.9,1 \mathrm{H}, \mathrm{H}-5^{\prime}\right), 4.14\left(\mathrm{dd}, J_{\text {gem }}=\right.$ $\left.13.0, J_{2^{\prime}, 3^{\prime}}=3.5,1 \mathrm{H}, \mathrm{H}-2^{\prime}\right), 4.18\left(\mathrm{ddd}, J_{\mathrm{gem}}=12.8, J_{5^{\prime \prime}, 4^{\prime}}=8.2\right.$, $\left.J_{\mathrm{H}, \mathrm{P}}=1.8,1 \mathrm{H}, \mathrm{H}-5^{\prime \prime}\right), 4.20\left(\mathrm{dd}, J_{\mathrm{gem}}=12.6, J_{2^{\prime \prime}, 3^{\prime}}=4.6,1 \mathrm{H}\right.$, H-2"), 4.698 (ddd, $\left.J_{3^{\prime}, 2^{\prime \prime}}=4.6, J_{3^{\prime}, 4^{\prime}}=4.3, J_{3^{\prime}, 2^{\prime}}=3.5,1 \mathrm{H}, \mathrm{H}-3^{\prime}\right)$, $5.21\left(\mathrm{ddd}, J_{4^{\prime}, 5^{\prime}}=8.3, J_{4^{\prime}, 5^{\prime \prime}}=8.2, J_{4^{\prime}, 3^{\prime}}=4.3,1 \mathrm{H}, \mathrm{H}-4^{\prime}\right), 8.163$ (s, 1H, H-2), 8.261 (s, 1H, H-8); ${ }^{13} \mathrm{C}$ NMR (150.9 MHz, $\mathrm{D}_{2} \mathrm{O}, T$ $\left.=25^{\circ} \mathrm{C}, \mathrm{pD}=5.9\right) 49.06\left(\mathrm{~d}, J_{\mathrm{C}, \mathrm{P}}=5.2, \mathrm{C}-5^{\prime}\right), 55.63\left(\mathrm{C}-2^{\prime}\right)$, 57.39 (C-4'), 72.34 (C-3'), 120.82 (C-5), 143.66 (C-8), 152.04 (C-4), 154.90 (C-2), 157.95 (C-6), 178.91 (d, $J_{\mathrm{C}, \mathrm{P}}=197.9$, $\mathrm{P}-\mathrm{CO}) ;{ }^{31} \mathrm{P}\left\{{ }^{1} \mathrm{H}\right\}$ NMR $\left(202.3 \mathrm{MHz}, \mathrm{D}_{2} \mathrm{O}, T=25^{\circ} \mathrm{C}, \mathrm{pD}=5.9\right)$ -2.30 .

\section{Supporting Information}

The $\mathrm{pD}$ titration curves of $\mathbf{9}$ and $\mathbf{1 0}$, the variable temperature NMR of $\mathbf{1 4}$, the pyrrolidine-ring parameterization for $9,10,13$ and 14 , the NMR signal assignments and copies of the ${ }^{1} \mathrm{H},{ }^{13} \mathrm{C}$ and ${ }^{31} \mathrm{P}$ NMR spectra are given.

\section{Supporting Information File 1}

Additional experimental data.

[http://www.beilstein-journals.org/bjoc/content/ supplementary/1860-5397-10-205-S1.pdf]

\section{Acknowledgements}

This work was supported by the Czech Science Foundation (Project No. 13-24880S).

\section{References}

1. De Clercq, E.; Sakuma, T.; Baba, M.; Pauwels, R.; Balzarini, J.; Rosenberg, I.; Holý, A. Antiviral Res. 1987, 8, 261-272. doi:10.1016/S0166-3542(87)80004-9

2. Balzarini, J.; Naesens, L.; Herdewijn, P.; Rosenberg, I.; Holý, A.; Pauwels, R.; Baba, M.; Johns, D. G.; De Clercq, E. Proc. Natl. Acad. Sci. U. S. A. 1989, 86, 332-336. doi:10.1073/pnas.86.1.332

3. Mackman, R. L.; Boojamra, C. G.; Prasad, V.; Zhang, L.; Lin, K.-Y.; Petrakovsky, O.; Babusis, D.; Chen, J.; Douglas, J.; Grant, D.; Hui, H. C.; Kim, C. U.; Markevitch, D. Y.; Vela, J.; Ray, A.; Cihlar, T. Bioorg. Med. Chem. Lett. 2007, 17, 6785-6789. doi:10.1016/j.bmcl.2007.10.038

4. Kočalka, P.; Rejman, D.; Vaněk, V.; Rinnová, M.; Tomečková, I.; Králiková, Š.; Petrová, M.; Páv, O.; Pohl, R.; Buděšínský, M.; Liboska, R.; Točík, Z.; Panová, N.; Votruba, I.; Rosenberg, I. Bioorg. Med. Chem. Lett. 2010, 20, 862-865. doi:10.1016/j.bmcl.2009.12.081

5. Rejman, D.; Panová, N.; Klener, P.; Maswabi, B.; Pohl, R.; Rosenberg, I. J. Med. Chem. 2012, 55, 1612-1621. doi:10.1021/jm201409u

6. Keough, D. T.; Hocková, D.; Rejman, D.; Špaček, P.; Vrbková, S.; Krečmerová, M.; Eng, W. S.; Jans, H.; West, N. P.; Naesens, L. M. J.; de Jersey, J.; Guddat, L. W. J. Med. Chem. 2013, 56, 6967-6984. doi:10.1021/jm400779n

7. Freier, S. M.; Altmann, K.-H. Nucleic Acids Res. 1997, 25, 4429-4443. doi:10.1093/nar/25.22.4429

8. Karplus, M. J. Am. Chem. Soc. 1963, 85, 2870-2871. doi:10.1021/ja00901a059

9. Altona, C.; Sundaralingam, M. J. Am. Chem. Soc. 1972, 94, 8205-8212. doi:10.1021/ja00778a043 
10. De Leeuw, F. A. A. M.; Altona, C. J. Comput. Chem. 1983, 4, 428-437. doi:10.1002/jcc.540040319

11. Padrta, P.; Sklenář, V. J. Biomol. NMR 2002, 24, 339-349. doi:10.1023/A:1021656808607

12. Hendrickx, P. M. S.; Martins, J. C. Chem. Cent. J. 2008, 2, No. 20. doi:10.1186/1752-153X-2-20

13. Sharma, N. K.; Ganesh, K. N. Tetrahedron 2010, 66, 9165-9170. doi:10.1016/j.tet.2010.09.082

14. Watts, J. K.; Sadalapure, K.; Choubdar, N.; Pinto, B. M.; Damha, M. J. J. Org. Chem. 2006, 71, 921-925. doi:10.1021/jo051844+

15. Rejman, D.; Kočalka, P.; Buděšínský, M.; Pohl, R.; Rosenberg, I. Tetrahedron 2007, 63, 1243-1253. doi:10.1016/j.tet.2006.11.047

16. Christensen, J. J.; Rytting, J. H.; Izatt, R. M. J. Phys. Chem. 1967, 71, 2700-2705. doi:10.1021/j100867a047

17. Christensen, J. J.; Rytting, J. H.; Izatt, R. M. Biochemistry 1970, 9 , 4907-4913. doi:10.1021/bi00827a012

18. De Leeuw, H. P. M.; Haasnoot, C. A. G.; Altona, C. Isr. J. Chem. 1980, 20, 108-126. doi:10.1002/ijch.198000059

19. Houseknecht, J.; Altona, C.; Hadad, C. M.; Lowary, T. L. J. Org. Chem. 2002, 67, 4647-4651. doi:10.1021/jo025635q

20. Rejman, D.; Pohl, R.; Kočalka, P.; Masojídková, M.; Rosenberg, I. Tetrahedron 2009, 65, 3673-3681. doi:10.1016/j.tet.2009.02.071

21. Gaussian 09, Revision D.01, Frisch, M. J.; Trucks, G. W.; Schlegel, H. B.; Scuseria, G. E.; Robb, M. A.; Cheeseman, J. R.; Montgomery, J., J. A.; Vreven, T.; Kudin, K. N.; Burant, J. C.; Millam, J. M.; Iyengar, S. S.; Tomasi, J.; Barone, V.; Mennucci, B.; Cossi, M.; Scalmani, G.; Rega, N.; Petersson, G. A.; Nakatsuji, H.; Hada, M.; Ehara, M.; Toyota, K.; Fukuda, R.; Hasegawa, J.; Ishida, M.; Nakajima, T.; Honda, Y.; Kitao, O.; Nakai, H.; Klene, M.; Li, X.; Knox, J. E.; Hratchian, H. P.; Cross, J. B.; Bakken, V.; Adamo, C.; Jaramillo, J.; Gomperts, R.; Stratmann, R. E.; Yazyev, O.; Austin, A. J.; Cammi, R.; Pomelli, C.; Ochterski, J. W.; Ayala, P. Y.; Morokuma, K.; Voth, G. A.; Salvador, P.; Dannenberg, J. J.; Zakrzewski, V. G.; Dapprich, S.; Daniels, A. D.; Strain, M. C.; Farkas, O.; Malick, D. K.; Rabuck, A. D.; Raghavachari, K.; Foresman, J. B.; Ortiz, J. V.; Cui, Q.; Baboul, A. G.; Clifford, S.; Cioslowski, J.; Stefanov, B. B.; Liu, G.; Liashenko, A.; Piskorz, P.; Komaromi, I.; Martin, R. L.; Fox, D. J.; Keith, T.; Al-Laham, M. A.; Peng, C. Y.; Nanayakkara, A.; Challacombe, M.; Gill, P. M. W.; Johnson, B.; Chen, W.; Wong, M. W.; Gonzalez, C.; Pople, J. A.; Gaussian, Inc.: Wallingford CT, 2009.

22. Becke, A. D. J. Chem. Phys. 1993, 98, 5648-5652. doi:10.1063/1.464913

23. Lee, C.; Yang, W.; Parr, R. G. Phys. Rev. B 1988, 37, 785-789. doi:10.1103/PhysRevB.37.785

24. Cossi, M.; Rega, N.; Scalmani, G.; Barone, V. J. Comput. Chem. 2003, 24, 669-681. doi:10.1002/jcc.10189

\section{License and Terms}

This is an Open Access article under the terms of the Creative Commons Attribution License

(http://creativecommons.org/licenses/by/2.0), which permits unrestricted use, distribution, and reproduction in any medium, provided the original work is properly cited.

The license is subject to the Beilstein Journal of Organic Chemistry terms and conditions:

(http://www.beilstein-journals.org/bjoc)

The definitive version of this article is the electronic one which can be found at:

doi:10.3762/bjoc. 10.205 